\begin{tabular}{ll}
\hline 綜 & 説 \\
\hline
\end{tabular}

\title{
気道再建手術の適応と方法
}

*石 原 恒 夫

\section{Reconstruction of Trachea and Bronchus}

Tsuneo Ishihara, M. D.

Department of Surgery, School of Medicine, Keio University, Tokyo

With recent progress in surgical techniques and postoperative managements, radical operations for lesions in the trachea and bronchus have been aggressively performed. Tracheoplasty is mainly performed in patients with tracheal stenosis secondary to tracheostomy, tracheal invasion of thyroid carcinoma, tracheal injuries and primary malignant tumors. Bronchoplasty is performed in patients with lung cancer, tuberculosis, bronchial injuries and benign tumors. Operations for lesions in the tracheobronchus consist mainly of sleeve resection and end-to-end anastomosis. It is now evident that primary anastomosis is possible even if it necessitates a wide resection of the trachea.

In tracheobronchoplasty, not only operative technique but also anesthetic technique is important. Accumulation of carbon dioxide and the occurrence of arythmia should be prevented.

This paper summarizes the indicaion, surgical method and anesthetic technique for surgery of the tracheobronchus.

最近とみに気道再建手術が注目されてきたととは喜 ばしいことである。わが国に括いても，すでと20年余 りの歴史をもっている手術であるが, 数年前までは, この手術は一部の人達の関心をひいていただけであっ た。

医学会に颃ける気道再建のたどってきた道を振り返 ってみると，1つの epoch は第 14 回日本気管食道科 学会総会にあった。昭和37年に金沢市で開催された本 総会に颃いて「気道拉よび食道の成形」がはじめてシ ンポジゥムに取り上げられた。ついで昭和 43 年の第 20 回総会では「気管気管支の再建」がシンポジウムとし て基礎的方面と臨床的方面に分けて論じられ，更に昭 和48年の第25回総会では再び「気道・食道の再建術, その後の進歩」がシンポジウムとして取り上げられ た。

このように日本気管食道科学会に颃いては早くから 気道再建が取り上げられていたが，広く胸部外科医の *慶応義塾大学医学部外科
関心をひくまでには至らなかった。しかし，昭和 50 年, 第28回日本胸部外科学会総会飞打いて曲直部寿夫 会長が「気管・気管支の手術」をシネシンポジウムと して，また「機能改善を目的とした呼吸器外科をシン ポジウムとして取り上げてからは, 胸部外科領域には 俄かに気道再建に対する関心が高まった。漸く高まっ てきた気管気管支の手術に対する関心は日本外科学会 飞屯波及し，昭和51年，第76回日本外科学会総会飞未 いて石川七郎会長は「気管気管支成形を伴う肺手術」 を主題の 1 つに選び，翌52年の第77回総会では村上忠 重会長は「気管 (支) 形成を伴う肺切除」をシネシン ポジウムに取り上げた。長らく気管気管支の外科に取 りくんできたものにとっては隔世の感を覚えざるをえ ない。

慶大外科飞扔いて気管支成形術がはじめて臨床例飞 行われたのは昭和 30 年10月24日であった。症例は結核 性の左主気管支狭窄を認めた29歳の男子で, 端々吻合 ではなく，気管支狭窄部を開大する Gedauer 方式 
による皮屚弁移植が試みられた。経過は良好であっ $た^{1,2)}$ 。

その頃, 大阪大学第 1 外科飞括いても, 腺様囊胞癌 に対して sleeve resection が行われていた。昭和 30 年 4 月 6 日である。この患者は術後 22 年, 健在してい ると聞いている3)。

慶大外科飞招ける第 2 例目の気管支成形術は昭和 31 年 3 月 30 日に行われた。この症例は25歳の女子で, 第 1 例と同じく結核性の左主気管支狭窄であった。この 第 2 例に対してはじめて狭窄部を切除して端々吻合で 気管支を再建する術式が選ばれた。当時 1 人の医局員 の友人に每日新聞の学術の記者がいてこの人がこの画 期的な手術の記事を畵いた。

沢山の動物で実験を重ねてきたあとではあったが， はじめての端々吻合には時間がかかった。手術手技も 麻酔も輸液も今日の技術水準には程遠いものであった のであろう。徹夜で術後管理にあたったスタッフの努 力の甲斐もなく, この患者は術後第 1 病日急性肺水腫 で死亡した。輝かしい新聞の報道が却ってわれわれに むなしさを与えた。

あれからすでと 20 余年が過ぎた。手術手技は進歩 し, 気道再建手術の成功例が多数報告されるようにな った。

昨年の第30回日本胸部外科学会総会において,「気 管支形成」がラウンドテーブルディスカッションの主 題飞選ばれたのを機会に，筆者は気道再建手術の全国 集計を行った。その詳細な別誌にゆずるが4)，昭和52 年 7 月末までに, 気管成形術は全国45施設で 195 例 に, 気管支成形術は44施設で 285 例飞行われていた。 気管成形術をうけた症例は気管切開後の気管狭窄が61 例でもっとも多く, 甲状腺癌気管浸潤の 44 例, 外傷の 42例, 原発性気管癌の37例がこれについでいた。気管 支成形術では肺癌が 157 例でもっとも多く, 結核性洀 痕狭窄の70例がこれについでいた。外傷は26例集計さ れた。

本稿に抬いては漸く注目を谷びてきた気道再建手術 について全国集計の結果を参考にしながら適応と手術 方法を中心に考察を加兄てみた。

\section{適応について}

\section{気管成形術}

1. 気管切開後の気管狭窄

気管切開口に生じた肉芽による狭窄と5,6) 気管力二 ューレの先端の刺激により生じた肉芽による狭窄と7), カフの圧迫により気管壁が変性したために生ずる狭

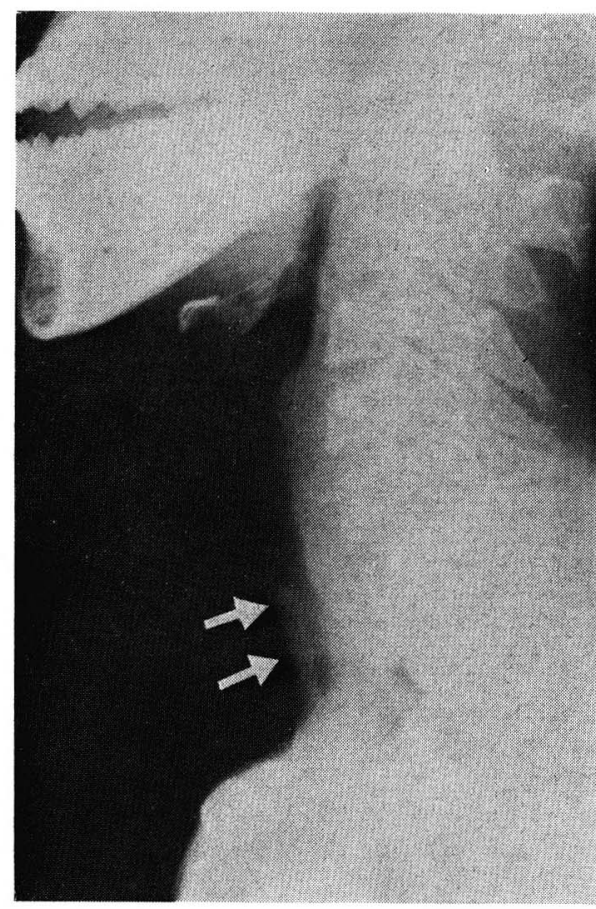

図 1 気管チューブのカフの圧迫で生じ た気管狭窄 (矢印)

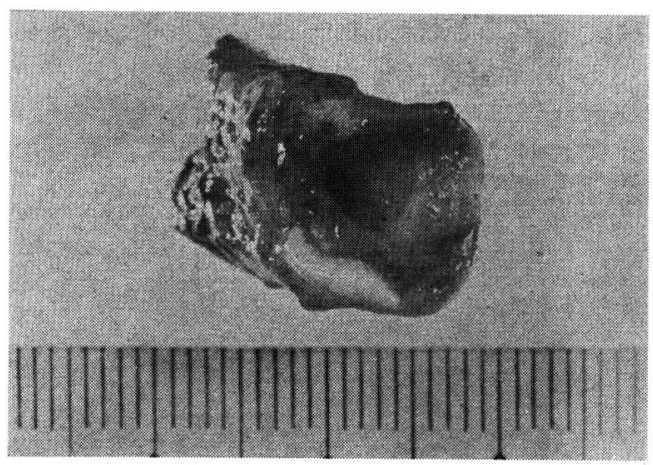

図 2 図 1 の症例の気管狭窄部の切除標本。, 気 管内腔は著明に狭窄している

窄5,7-12) とある。図 1 は気管内插管し, レスピレータ 一を用いて人工呼吸を行った症例の気管のX線写真で ある。カフの圧迫により気管に範囲の広い狭窄が発生 した。図 2 は本例の気管の切除標本である。気管を 4 気管輪含めて切除し，端々吻合で気道を再建した。術 前は安静時にも碝鳴が認められたが, 術後は喘鳴は全 く消失した, 図 3 は本症例の術後の気管造影である。 このような気管狭窄に対して保存的な治療を試みるこ とは危険で, 内径が $1 / 2$ 以下に狭窄したものでは観血 


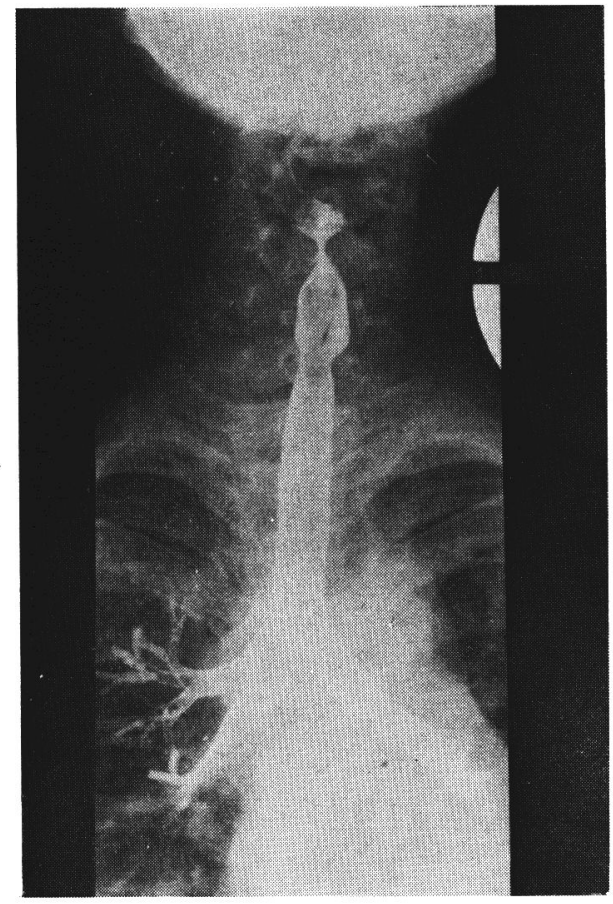

図 3 図 1 亿示した症例の術後の気管造影写真 気管が短縮したために気管分岐部が釣り上 っているが，ほか著変はない

的飞治療すべきである。

2. 外傷

新鮮外傷と陳旧外傷とある。新鮮外傷でも気管の損 傷の明らかな症例では問題はないが，気管損傷の症状 の出にくいものでは外傷を見逃し易いので注意を要す る。頸部外傷で血痰を認めるときは気管損傷が明らか でなくても，気管支鏡検査を行って，損傷の有無を確 かめた方がよい。損傷が部分的で創の哆開がなけれげ 保存的飞治療しても良いが13), 損傷が半周以上飞及ぶ ときは，損傷部位を手術的に処置すべきである。これ を放置すると次に述べる陳旧性の瘦痕狭窄 ${ }^{14}$ となる。 すなわち気管外傷に対し適切な治療を行わないと受傷 $3 \sim 4$ 週後, 喘鳴, 呼吸困難の症状が現われ, 気管狭 窄の存在が明らかとなってくる。

新鮮な気管損傷に対する縫合は, 陳旧性の搬痕狭窄 の手術よりも手技が安全で，かつ容易であるので，新 鮮外傷を見逃すことのないように注意すべきであろ う。

しかし，集計した全国諸施設の成績をみると新鮮な 気管損傷の手術例では吻合部狭窄や縫合不全の発生率 が比較的高かった。気管が損傷すると周辺の血液が気
道内に流入し，病態が重篤に見学がちである。合併症 の発生率の高いのは縫合を急ぐあまり, 操作が不正確 になるためかも知れない。気道を確保し止血を確実に 行えば，縫合は容易なはずである。

3. 腫 瘍

気管飞発生する原発性腫瘍飞は悪性腫瘍と良性腫瘍 があるが，われわれが日常接するものは忹とんどが悪 性腫瘍である。原発性腫瘍そのものの類度は少いが, 悪性腫瘍としては扁平上皮癌15-23), 腺様囊胞癌 ${ }^{16-19}$, 24-37)，平滑筋肉腫 ${ }^{7,37)}$ などが報告されている。気管成 形術が今日のように普及する前は，これらの腫瘍に対 しては鉗子による内視鏡的な切除や照射が行われてい た。しかし，鉗除も照射も姑息的で根治しうるもので はない。

腺様囊胞癌では, 肉眼的な腫瘍の境界よりも広く浸 潤しているものが多い, Pearson 5 ${ }^{33)}$ は腫瘍の肉眼的 境界線よりむ $1 \mathrm{~cm}$ 離れて気管を切除すべきであると 述べているが，われわれも腫瘍が境界と思われる部分 より組織学的には，1気管輪進展していた症例を経験 している。悪性腫瘍に打ける気管成形術では, 術中に 気管の両断端を組織学的に詳しく検索しなければなら ないことを物語っているものであるう。

気管の原発腫瘍とは別に周囲臟器に発生した悪性腫 瘍が気管壁飞浸潤してきて, 気管内腔に腫瘍が増生し てくるものがある。甲状腺癌 $16,32,37-46)$ がもっとも多 いが，副甲状腺癌 ${ }^{47}$ ，食道癌 ${ }^{48}$ 飞も気管壁へ浸潤する ものがある。図 4 は甲状腺癌の気管浸潤例の切除標本 である。隣接蔵器に発生した癌がこのように気管内腔 に浸潤してくるのである。

腫瘍が 2 次的飞気管飞浸潤してきたものでは，放置 すると腫瘍が内腔を閉塞して窒息することがあるの

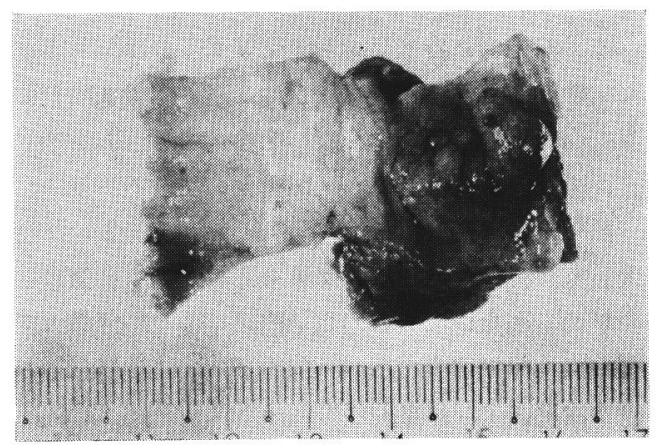

図 4 甲状腺癌が浸潤した気管壁の切除標本。気 管を維に開いたところである。癌が内腔に盛 り上っている 
で，原発腫瘍を根治できる見込みがなくても，気管の 病変部を切除する必要がある。

\section{4. 先天性気管狭窄}

稀な奇形ではあるが新生児あるいは幼小児に喘鳴， 呼吸困難を認めるときは気管狭窄の存在する可能性も あるので胸部X線写真撮影, 気管支鏡検査を行って精 査すべきである。横撮りの写真が有用であるといわれ ているが49)，深い斜位で撮った写真も気管をみるため には便利である。先天性気管狭窄では気管軟骨が馬締 型をとらず融合して輪状となり膜模部を欠いている。 全気管にこのような気管軟骨の融合を認める症例で は，その治療は難しいが50)じょうろ型の狭窄や気管の 一部分に分節状に狭窄を認めるものでは気管成形術の 適用により気道の確保がえられるので，早い時期に観 血的飞奇形をな括すべきであろう。

\section{気管支成形術}

\section{1. 肺 癌}

わが国飞招いてもっとも多くこの手術の対象となっ ているのは肺癌である。初期飞行った肺癌手術例に局 所再発がみられたために, 肺癌でこの手術の適応飞人 るものは少いのではないかといわれた時代むあった が，今日ではこの術式の応用によって肺癌手術の適応 はむしろ拡大されている。

通常の肺葉切除術では根治性飞疑問の残る症例飞対 して，一側肺全切除の適用を検討する前にこの術式の 適用をまず考えてみるべきであろう。機能的に一側肺 全切除が可能であっても術後の回復は sleeve lobectomyの方が早いし, 回復の程度も異る51)。

また，従来の手術法では切除の適応外飞拮かれてい た気管分岐部や下部気管に浸潤した肺癌の中にも，気 管気管支成形術の応用によって根治しうる症例が $3^{52,53)}$ 。図 5 は, 右上葉気管支飞発生した肺癌が下部 気管にまで浸潤した症例の術前の気管支鏡写真であ る。この症例では右上葉を右主気管支，下部気管とと もに切除し，気管と左主気管支括よび右中幹を吻合し て新しい気管分岐部を作った。術後 2 年 5 力月を過ぎ たが, 再発の徴候はなく, 元気に㗢いている。

\section{2. 結核性気管支狭窄}

太い気管支の結核性気管支炎を主徵とする肺結核症 が今日でも跡を絶たない。化学療法により結核性炎が 消筤しても般痕狭窄を残して治療すると末梢肺領域に 感染を繰返すようになるので，気管支狭窄を治療する 必要が生ずる。

全国集計により結核性瘢痕狭窄の手術成績をみると 術後の吻合部狭窄が高率飞発生していた。術前の化学

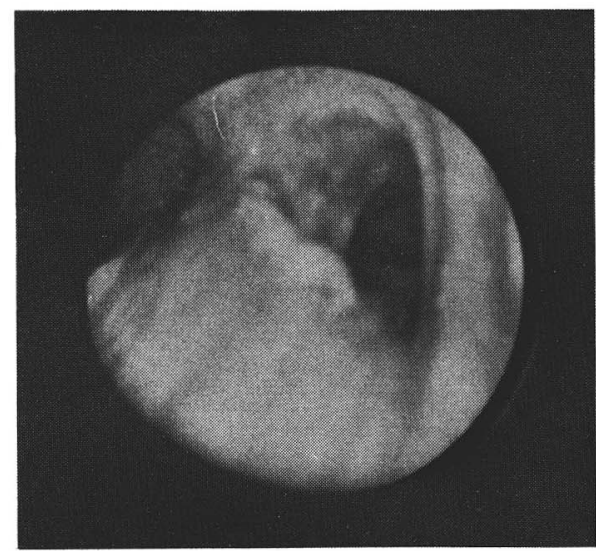

図 5 右主気管支に発生した肺癌が気管分岐 部をこえて下部気管にまで浸潤した症例 の気管支鏡写真

療法が不十分であったのか, 狭窄部が広範囲であった ために，吻合がうまく行かなかったのか詳紐は分らな いが，悪性腫瘍の症例と異り，結核例では必ずしも健 全な気管支壁で吻合できるとは限らないので，術前の 化学療法の効果を適格飞評価し, 手術時期を慎重飞き めることが，合併症を防止する要点ではないかと思わ れる。

3. 外 傷

閉鎖性胸部外傷により主気管支が横切されることが ある7,54-66)。胸廓が前後に強く圧縮されると横径がの び，左右の主気管支に気管分岐部を外側飞斢引する力 が加わるのである。この時期に声門が閉じていると, 気道内圧は上り, 父管支が断裂し易い状況が生ずる。 通常, 気管分岐部から $2 \mathrm{~cm}$ 以内の左右の主気管支が 断裂する67)。図6 恃交通事故により胸を強打した症例 の受傷後12時間の気管支鏡写真である。この症例では 右主気管支が完全に離断していた。図 7 はこの症例の 受傷36時間後の気管支鏡写真である。

このような症例は気管支成形術の適応飞人るもの で, 受傷後早期に手術的飞処置すべきである。

\section{手術手技について}

\section{病変部への到達経路}

筆者が用いている病変部への到達経路について述べ る。

病変部が頸部父管や頸胸移行部の父管にあるとき は, 前頸部の襟状切開で病変部に到達している。襟状 切開のみでは視野が十分にえられないときは，これに 胸骨縦切開を追加した。 


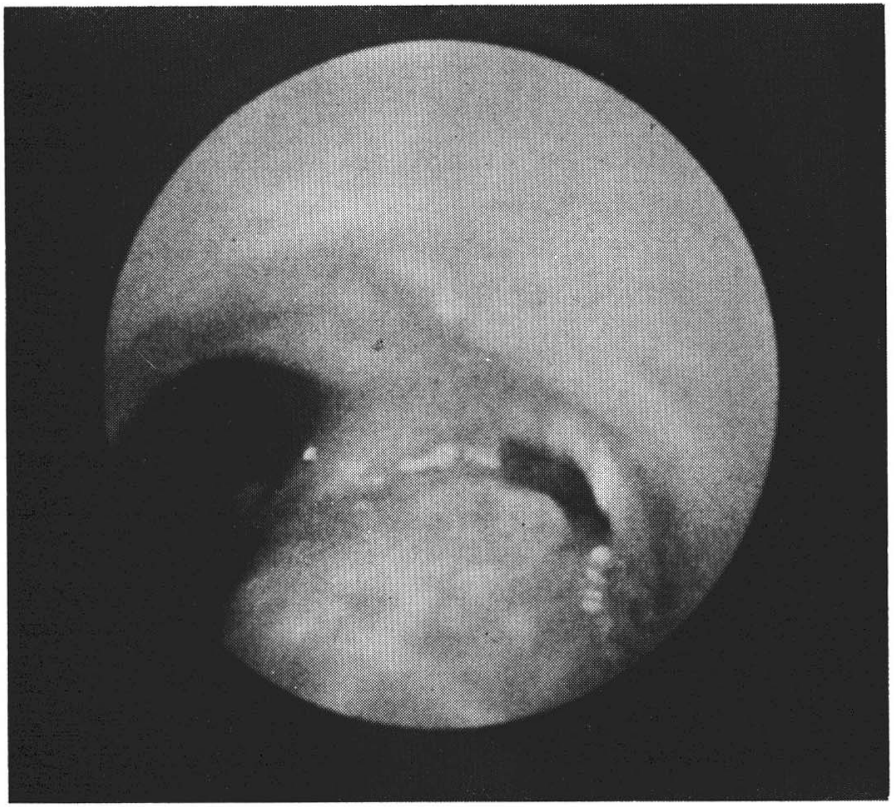

図 6 閉鎖性胸部外傷飞よる右主気管支完全離断例の受傷後 12 時間の気管支鏡写真

右主気管支は完全飞離断しているょうにはみえない

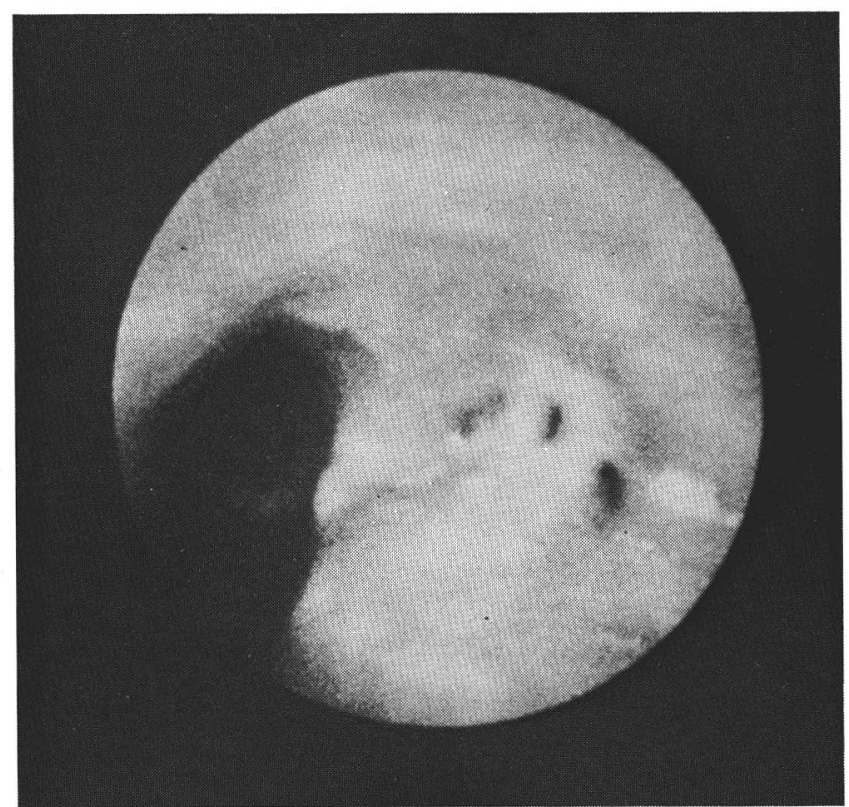

図 7 図 6 と同じ症例の受傷後36時間の気管支鏡写真 気管支鏡所見は時間とともに変化し，右主気管支は閉塞してき ている
気管の下 3 分の 1 亿病変部分があ るときは右開胸で気管に到達してい る。

気管への到達経路の如何によって 気管成形術の難易が左右されるの で, 到達経路については慎重に検討 すべきである。

主気管支に病変があるときは，普 通の開胸術に準じて開胸している。

\section{切除範囲}

気管はその $60 \%$ を切除しても端々 吻合で再建できるということは今日 では明らかである68-70)。人間の気 管は長さ約 $11 \mathrm{~cm}$ ，気管輪の数は 15 〜 19個, 平均 16.5 個である71)。従っ て10気管輪切除をしても端々吻合に より気管を再建することができると いってよい。筆者らは気管輪を10個 扣よび 9 個切除した後, 端々吻合で 気管を再建した症例をそれぞれ 2 例 経験しているが，これら 4 例の中に 吻合部が哆開したものはない。

主気管支の成形術では切除範囲に 悩むことは少い。しかし，左側では 主気管支切除して，端々吻合する と，大動脈弓に左上葉支がさえぎら れて，吻合部飞予期しない張力がか かることがある。吻合部が気管分岐 部の近くに来るときは主気管支の切 除量はかなり制限されると思った方 がよい。

主気管支の結核性の症痕狭窄例で 狭窄部の範囲が長いものは, 狭窄の 著しい部分のみを切除し, 残存した 狭窄部は壁の内側面をけずりとって 内腔を広くし，それから吻合するの も 1 つの方法である。炎症性飞壁全 体が肥厚しているので, 壁の内側面 をけずりとっても壁が弱くなること はない。筆者はこのような方法を時 々用いているが, 結果は良好であ る。

\section{吻合法}

縫合系は筆者は初期には chromic catgutを用い, 後ナイロン系にか 
え, 現在ではプロリーン糸を用いている。テフデック 糸を用いたとともあるが，筆者らが使用してきた縫合 糸の中ではプロリーン糸がもっとも良いように思われ る。

縫合法は粘膜下飞針を通し，内腔飞系が出ないよう にすること，また気管や気管支の断端の軟骨が上下き ちっと合うようにすることが必要である。

減張縫合は行わない。吻合部を胸膜片などで被覆す ることもしていない。縫合は一層で十分である。

\section{補 填}

補填方法としては，今日までいろいろの方法が報告 されているが, 胸膜による補媜 ${ }^{21,74)}$ とメッシュによる 補填 $\left.{ }^{75}, 76\right)$ が気管壁の部分的欠損の修復に用いられて成 功している。

しかし，切除範囲が広く，端々吻合では気管を再建 できないときには全周補填の問題が生してくる。人工 気管を臨床に用いて成功した報告は長らく聞かなかっ たが，最近 Neville ら 77) 気管の全周欠損の修復に， silicon rubber prosthesis を用い，輝かしい成績を上 げている。

\section{麻 酔}

気管気管支成形術の麻酔には 2 つの意味がある。1 つは疼痛からの解放であり，1つは換気の維持であ る。狭窄の強い症例では特に換気が問題になる。

麻酔の技術的な難しさは気管の病変部が気管分岐部 に近くなる程，きびしくなるようである。

頸部気管に病変があるときは，筆者は局所麻酔で手 術をはじめ, 気管の病変部に達したところで, 病変部 より肺側の気管を切開し，ここに消毒した気管チュー ブを術野から插管して全身麻酔飞切りかえている。

吻合のすべてを気管チューブを術野から插入したま まで行うことには無理があるので，気管の後ろ半分に 縫合系をかけたところで, 術野から口腔に向って消毒 した気管チューブを逆行插管し，先に挿入してあった チューブを抜去してて，逆行捜管したチューブの先端を 気管の肺側断端に挿入している。こうすると形は通常 の気管内捙管となるが，術野に露出した気管チューブ は清潔なので，術野が污染されることがない。

胸腔内気管の病変飞対しては経口插管による全身麻 酔で手術をはじめているが, 開胸後は術野捰管, 逆行 挿管の手順に従って手術をしている。

この術野插管による麻酔法には換気の中断がない。 問題があるとすれげ気管に到達して, 術野から插管す るまでの間の換気である。狭窄部が気管分岐部に近づ く程，麻酔の手技が難しくなると先に述べたのはその
ことである。

術野から挿管するまでの間, 気管狭窄部を越えて細 い（テフロン針のような）チューブを插入し, venturi の原理を応用した jet 換気を利用するのも 1 つの方法 である72)。

筆者は頸部気管の狭窄の著しい症例に, 術野から気 管の健常部に插管するまでの間, 部分体外循環を用い たことがある73)。体外循環を用いた時間は32分間であ り, この症例に関する限り, 麻酔の維持には成功し た。しかし, 術後創からの実質性の出血が多量で, 創 の治瘾は遷延した。体外循環は症例を選んで用いれ ば，有効な補助手段であるが，みだりに用いる心゙きも のではないと思われる。

\section{術後管理について}

気管気管支成形術後の患者は通常の開胸術後の患者 と異り, 気道内分泌物の喀出が自力では十分にできな い。術後管理の最大の要点は気道内分泌物の排除であ る。自力で十分に喀出できない時期には nasotrachcal suction か気管支ファイバースコープを用いて分泌物 を取り除くことが必要である。

\section{合併症について}

縫合不全 ${ }^{4)}$, 吻合部狭窄 ${ }^{4)}$, 喀血 ${ }^{22,77-80)}$ などの合併 症が報告されている。これらの詳細については別に述 べた ${ }^{81)}$

\section{手術成 績}

先に紹介した，気管気管支成形術の全国集計に現わ れた手術成績は必ずしもよくなかった。気管成形術で は合併症が $20.5 \%$ 、, 手術死亡は $7.2 \%$ とみられ, 気 管支成形術では合併症が $14.4 \%$ 亿，手術死亡は $4.9 \%$ そみられた。合併症の多くは吻合部狭窄や縫合不全で 占められ，手術手技に改良すべき点が多々残されてい ることが示された。

筆者らは現在までと73例の気管気管支成形術を行っ たが、手術死亡招よびそれに準ずるものを 4 例経験し た。 4 例中の 2 例は甲状腺癌の気管浸潤例であり， 1 例は肺癌で分岐部を切除した症例であり，1例は冒頭 に述べた術後第 1 病日急性肺水腫で死亡した気管支成 形の 1 例である。

気管成形 3 例のうちの 2 例は突如発来した大量出血 のため術後24日括よび 4 力月に死亡した。1 例は甲状 腺癌の進展例で縫合不全が手術死亡の原因となった。

これらの症例はわれわれの常用している手術手技と 
手術適応の選択に多くの示唆を与兄た。

\section{ま と め}

気道再建手術の適応, 手術手技, 麻葘法, 術後管 理, 手術成績についてとの手術の歴史を振り返りなが ら記した。

\section{文献}

1) 道躱祐二郎䚾加：第 9 回日本胸部外科学会総会発 表 (1956).

2) 道躱祐二郎ほか：第10回日本胸部外科学会総会発 表 (1957).

3) 前田昌純 : 私信 (1978).

4) 石原恒夫ほか：わが国に打ける気管気管支成形術 の現況, 日胸外会誌, 26巻 8 号, 1978年揭載予定.

5) Fishman, N.H. et al : Postintubation tracheal stenosis, Ann. Thoracic Surg. 8: 47, 1969.

6) 石原恒夫 : 気管狭窄飞詨寸万気管成形術の応用, 手術, $24: 1452,1970$.

7) 石原恒夫ほか：気管気管支成形術, 胸部外科, 28: 761, 1975.

8) Pearson, F.G. \& Andrews, M.J. : Detection and management of tracheal stenosis following cuffed tube tracheostomy. Ann. Thoracic Surg. 12: 359, 1971.

9) Grillo, H.C. et al: A low-pressure cuff for tracheostomy tubes to minimize tracheal injury. A comparative clinical trial. J. Thoracic Cardiovasc. Surg. $62: 898,1971$.

10) Goldberg, M. \& Pearson, F.G.: Pathogenesis of tracheal stenosis following tracheostomy with a cuffed tube. An experimental study in dogs. Thorax $27: 678,1972$.

11) Ching, N.P.H. et al: Endotracheal damage during continuous ventilatory support. Ann. Surg. $179: 123,1974$.

12) Dunn, C.R. et al.: Determinants of tracheal injury by cuffed tracheostomy tubes. Chest 65 : 128, 1974.

13）前中由己：最近の災害外傷の特異性, 胸部外傷, 現代外科学大系年刊追補，1976-A, p. 61-88, 中山 書店, 東京.

14）道躰祐二郎ほか：外傷性頸部気管狭窄の気管成形 術飞よる治験例, 胸部外科, $12: 27,1959$.

15）早田義博ほか：原発性気管腫瘍の外科, 日気食会 報, $13: 179,1962$.

16) Mathey, J. et al: Tracheal and tracheo-bronchial resections techniques and results in twenty cases. J. Thoracic Cardiovasc. Surg. 51 : 1, 1966.

17) Perelman, M. \& Korolyova, N.: Surgery of tumours in the thoracic portion of the trachea. Thorax $23: 307,1968$.

18) Houston, H.E. et al: Primary cancers of the trachea. Arch. Surg. $99:$ 132, 1969.

19) Hajdu, S.I. et al Carcinoma of the trachea cli- nicopathologic study of 41 cases. Cancer $25: 1448$, 1970 .

20) Birt, B.D. :The management of malignant tracheal neoplasms. J. Laryngol. Otol. 84 : 723, 1970.

21) Childress, M.E.: Tracheogenic carcinoma. J. Thoracic Cardiovasc. Surg. 64 : 573, 1972.

22) Grillo, H.C. : Reconstruction of the trachea. Thorax $28: 667,1973$.

23）浜中雄二ほか：原発性気管癌の 1 剖検例と本邦報 告例飞打ける統計的観察。外科診療, $18: 531,1976$.

24) Macmanus, J.E. \& McCormick, R. : Resection and anastomosis of the intrathoracic trachea for pulmonary neoplasms. Ann. Surg. 139 : 350, 1954.

25) Grillo, H.C. et al : Resection of the carina and lower trachea. Ann. Surg. 158 : 889, 1963.

26) Smith, L.C. et al: Cylindroma (Adenoid cystic carcinoma). A report of fifty-eight cases. Am. J. Surg. $110: 519,1956$.

27) Grillo, H.C.: Management of cervical and mediastinal lesions of the trachea. J.A.M.A. 197: 1085, 1966.

28）小野讓注か：気管原発腫瘍 2 症例, 日気食会報, $19: 346,1969$.

29) Zunker, H.O. et al: Adenoid cystic carcinoma (Cylindroma) of the trachea. Case report with 9-year follow-up. Cancer $23: 699,1969$.

30) Richardson, J.D. et al: Adenoid cystic carcinoma of the trachea report to cobalt-60. J. Thoracic Cardiovasc. Surg. 66 : 311, 1973.

31) Singh, H.M. \& Thomas, D.M.E. : A clinical sign of adenocystic tumour of the trachea. Thorax $28: 442,1973$.

32) Perelman, M.I. \& Korolyova, S.N.: Trachealgeschwülste und die Chirurgische Behandlungen. Thoraxchirurgie Vaskuläre Chirurgie 21:500, 1973.

33) Pearson, F.G. et al : Adenoid cystic carcinoma of the trachea. Ann. Thoracic Surg. 18: 16, 1974.

34) Nakratzas, G. et al : Repeated partial endoscopic resection as treatment for two patients with inoperable tracheal tumours. Thorax 29:125, 1974.

35) Baydur, A \& Gottlieb, L.S.: Adenoid cystic carcinoma (Cylindroma) of the trachea masquerading as asthma. J.A.M.A. $234: 829,1975$.

36) Abudallo, K. et al: Primary tumors of the thoracic trachea with special emphasis on surgical management. International Surg. $61: 347,1976$.

37) 石原恒夫ほか：気管悪性腫瘍飞対する外科的治 療, 日気食会報, $28: 254,1977$.

38）三浦健ほか：喉頭，気管に浸潤した甲状腺癌の根 治的摘出術, 手術, 24:1366, 1970.

39）広戸幾一郎：気管飞浸潤せる甲状腺癌摘出後の気 管造成の一方法, 日気食会報, $21: 214,1970$.

40）松崎弘章ほか：甲状腺癌に対する気管合併切除の 手術経験, 外科, $33: 272,1971$. 
41) 富田正雄ほか：気管再建術の臨床的検討, 胸部外 科, $27: 482,1974$.

42) 峯田武興ほか：気管形成を行った甲状腺癌の 1 例, 手術, $28: 929,1974$.

43）岩喬ほか：気管浸潤を伴う覀性甲状腺腫に対する 外科治療一とくに気管形成術飞ついて一, 外科, $37: 933,1975$.

44）石原恒夫ほか：気管に浸潤した甲状腺癌の治療, 手術, $30: 195,1976$.

45）木村荘一ほか：甲状腺癌飞よる気管閉塞に対する terminal or mural tracheostomy $の 1$ 例, 抗研誌, $28: 37,1976$.

46) Ishihara, $T$. et al : Resection of thyroid carcinoma infiltrating the trachea. Thorax 33巻 1978 年 掲載予定.

47) Inoue, $\mathrm{H}$. et al: Parathyroid carcinoma with tracheal invasion and airway obstruction. Surgery 揭載予定.

48) Thompson, D.T.: Lower tracheal and carinal resection associated with subtotal oesophagectomy for carcinoma of oesophagus involving trachea. Thorax $28: 257,1973$.

49) Cantrell, J.R. \& Guild, H.G.: Congenital Stenosis of the Trachea. Am. J. Surg. $108: 297,1964$.

50）斎藤成司, 犬山径夫：先天性気管狭窄の一例, 日 気食会報, $21: 194,1970$.

51) Naef, A.P. \& Gruneck, J.S.: Right pneumonectomy or sleeve lobectomy in the treatment of bronchogenic carcinoma. Ann. Thoracic Surg. $17: 168,1974$.

52) 石原恒夫：気管分岐部に浸潤した肺癌の外科的治 療, 日胸, 35:734, 1976.

53) Ishihara, $T$. et al: Resection of cancer of lung and carina. J. Thoracic Cardiovasc. Surg. 73: 936, 1977.

54) Richards, V. \& Cohn, R.B.: Rupture of the thoracic trachea and major bronchi following closed injury to the chest. Am. J. Surg. $90: 253$, 1955.

55) Hood, R.M. et al: Injuries of the trachea and major bronchi. J. Thoracic Cardiovasc. Surg. $38: 458,1959$.

56) Paulson, D.L.: Traumatic bronchial rupture with plastic repair. J. Thoracic Surg. 29:636. 1951.

57) Mahaffey, D.E. et al: Traumatic rupture of left main bronchus successfully repaired eleven years after injury. J. Thoracic Surg. $32: 312$, 1956.

58) Peters, R. et al:Traumatic rupture of the bronchus a clinical and experimental study. Ann. Surg. $148: 871,1958$.

55) Chesterman, J.T. \& Satsangi, P.N.: Rupture of the trachea and bronchi by closed injury. Thorax $21: 21,1966$.

60) Larizadeh, R. : Rupture of the bronchus. Thorax
$21: 28,1966$.

61) Burke, J.F.: Early diagnosis of traumatic rupture of the bronchus. J.A.M.A. 181:682, 1962.

62) Drapanas, $T$. et al: Reversible poststenotic bronchiectasis. New Eng. J. Med. 275:917, 1966.

63) Eijgelaar, A. et al: A reliable early symptom of bronchial or tracheal rupture. Thorax $25: 120$, 1970.

64) Logeais, Y. et al: Traumatic rupture of the right main bronchus in an eight-year-old child successfully repaired eight years after injury. Ann. Surg. 172: 1039, 1970.

65) Schaar, H. et al : Successful late repair of a posttraumatic bronchial stricture. Thorax $27: 769$, 1972.

66）藤村重文ほか：鈍性胸部外傷による左主気管支の 完全離断と瘢痕性閉塞の 治験例, 胸部外科, 29 : 22, 1976.

67) Lloyd, J.R. et al: Rupture of the main bronchi in closed chest injury. A reproduction of the injury in the experimental animal, discussion of the possible mechanisms involved. A.M.A. Arch. Surg. $77: 597,1958$.

68) Grillo, H.C. et al: Extensive resection and reconstruction of mediastinal trachea without prosthesis or graft: an anatomical study in man. J. Thoracic Cardiovasc. Surg. 48 : 741, 1964.

69) Naef, A.P.: Extensive tracheal resection and tracheobronchial reconstruction. Ann. Thoracic Surg. $8: 391,1968$.

70) Dor, V. et al: Résection étendue de la trachée pour tumeur et sténose. Résultats immédiats et contrôles éloignes à propos de 16 cas. La Presse Med. $79: 1843,1971$.

71) 古泉桂四郎：気管の伸長能飞関する計測的研究, 日気食会報, $17: 294,1967$.

72）慶応義塾大学外科：気管成形術一麻酔科医との討 詥一, 胸部外科, $30: 208,1977$.

73) 深井志摩夫注か：人工心肺体外循環を用い気管切 除を行った再発甲状腺癌の1例, 外科, 40巻, 1978 年 印刷中.

74) Penton, R.S. et al: The use of a viable pedicle flap graft for repairing an extensive tracheobronchial defect. Ann. Surg. 135 : 709, 1952.

75) Keshishian, J.M. et al : Tracheal reconstruction. J. Thoracic Surg. $32: 707,1956$.

76) Beall, Jr., A.C. et al: Tracheal reconstruction with heavy marlex mesh. Arch. Surg. $86: 970$, 1963.

77) Neville, W.E. et al: Prosthetic reconstruction of the trachea and carina. J. Thoracic Cardiovasc. Surg. $72: 525,1976$.

78) Revilla, A.G. et al: Trachea innominate artery fistula after tracheal reconstruction. J. Thoracic Cardiovasc. Surg. 67 : 629, 1974. 
79) Arbulu, A. \& Thoms, N.W.: Tracheal innominate artery fistula after repair of tracheal stenosis. J. Thoracic Cardiovasc. Surg. 67 : 936, 1974.

80) Deslauriers, J. et al : Innominate artery rupture. A major complication of tracheal surgery. Ann. Thoracic Surg. $20: 671,1975$.
81) 石原恒夫 : 気道再建手術, 現代外科学大系年刊追 補, 1978, 中山畫店, 東京, 印刷中.

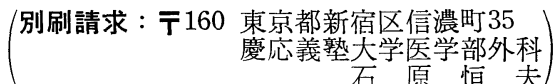

